\title{
Acquisition of the Inter-Dental Fricatives /ө/ and /ð/ in ESL/EFL and Jamaican Creole: A Comparative Study
}

\author{
Ahmed Mousa \\ King Abdulaziz University, Jeddah, KSA \\ Email: aimousa2004@yahoo.com \\ Received 9 September 2013; revised 12 October 2013; accepted 22 October 2013 \\ Copyright (C) 2014 by author and Scientific Research Publishing Inc. \\ This work is licensed under the Creative Commons Attribution International License (CC BY). \\ http://creativecommons.org/licenses/by/4.0/ \\ (c) () Open Access
}

\begin{abstract}
This study aims at investigating to what extent the linguistic processes exhibited in creolization parallel those manifested by Arab learners of English in particular and those of child language and second/foreign language in general. Another aim of the study is to highlight the link between second/foreign language learning and historical change. To this end, the speech of two speakers of the Broad Jamaican Creole was compared with the performance of Saudi school and university learners of English as a foreign language and data from child language, with respect to the pronunciation of English inter-dental fricatives $/ \theta /$ and $/ \delta /$. The results show that learning in the above three situations takes place according to the same principles. Furthermore, the sound substitutions made in the three situations (i.e. [t], [d] respectively) are the same as those witnessed in historical sound change.
\end{abstract}

\section{Keywords}

Inter-Dental Fricatives; ESL/EFL; Jamaican Creole; Saudi Learners of English

\section{Introduction}

The ultimate goal of linguists is to decipher the mystery of the logical problem of language learning. That is, linguists are concerned with how a normal five-year-old human child acquires mother tongue (c.f. Brown, 1973). Another important aim of modern linguistic theory is to come up with language universals - that is principles according to which all human beings speak a language (see Greenberg, 1966). Though it is important in the linguistic behaviour, the domain of phonology in second/foreign language learning and pidgin and creole languages has received little attention compared to the other aspects of language. Research has revealed that child language, second/foreign language learning and pidgin and creole languages are more or less related in terms of 
processing. Many phenomena in these fields have been shown to be similar (Cook, 1993; Bickerton, 1995; Washabaugh, 1977; Schumann, 1978 and Holm 2000). Moreover, research on processes of pidginization and creolization has led to important advances in a number of areas of applied linguistics and theoretical linguistics (c.f. Holm, 2000). In this study, the strategies of language learning reported in Mousa (1994) are compared to the process of creolization of two speakers of Board Jamaican Creole (Bailey, 1966). The similarities between the two creole speakers and Mousa's (1994) learners will be highlighted drawing on the assumption that "the dynamics by which pidgins and creoles come into being and the development of the L2 learner's interlanguage might be governed by the same factors” (Cook, 1993: p. 69). That is, in both situations the behaviour of those concerned is constrained by the principles of Universal Grammar, a genetically determined pre-disposition for language. Furthermore, we assume that second language learning, creolization and historical change are significantly linked in such a way that accounting for the behaviour of the first two is never precise in the absence of historical facts.

\section{Literature Review}

As an interesting and promising domain of linguistic research, the comparison of non-native language acquisition with pidginization/creolization has attracted a significant number of linguists. This is so, because researchers have come to realize that, in order to understand the behaviour of early and late second/foreign language learning, an appreciation of the processes involved in pidginization/depidginization, creolization/decreolization is a key issue (McLaughlin, 1987). For instance, Baxter et al. (1978), in their investigation of the Brazilian spoken dialect of Helvecia, observed a series of parallels with structures in early stages of L1 Portuguese acquisition.

In a comparison between the decreolization of the Guyanese Creole negation system and the acquisition of English negation by Spanish speakers, Schumann et al. (1978) found that the overall movement along the linguistic continuum in the two operations involved a rule change from a basilect/basilang preverbal negation to the target English post-copula auxiliary negation. Furthermore, it was observed that the above rule change in the situations was accomplished by identical linguistic processes- the replacement of surface forms and the restructuring of underlying units. Likewise, in the depidginization of Hawaiian Pidgin English, as reported by Bickerton and Odo (1976), a continuum of development occurs which is similar to that produced in decreolization and second language acquisition.

Patrick-Andre (2006), in a recent study, has come to the conclusion that many of the features found in Haitian French-lexifier creoles do occur in L2 French and other interlanguages, as a result of L1 transfer and other acquisition processes. The investigation includes word-order within the noun phrase, pronominal clitics, absence of copula, grammatical gender, and verb movement. The major claim of the model of creole genesis advocated in the study which he calls gradualist/second language acquisition, is that creole genesis does not involve any specific mental processes or strategies other than those attested in ordinary second language acquisition. In Lefebvre et al. (2003), a number of second language researchers and creolists engage in dialogues which focus on the processes characterizing various stages of L2 acquisition and creole genesis, such as relexification and transfer from L1 and their role in the initial state. The dialogues also cover morphological, phonological, semantic and syntactic properties of interlanguage grammar and creole grammars. Their findings lend support to the view that the same processes are found to shape the initial stages of the two situations.

\section{Current Study}

This study aims at investigating to what extent the linguistic processes exhibited in the creolization parallel those manifested by Mousa's (1994) learners in particular and those of child language and second/foreign language in general. In addition, it is assumed that foreign/second language learning and historical change are significantly linked in such a way that accounting for these learning situations is never precise without historical explanations. Thus, another aim of this study is to see to what extent the behaviour of the speakers of the Board Jamaican Creole and Mousa's learners exhibit facts of historical change. But before embarking on our investigation, introducing the Jamaican informants and the Saudi learners in Mousa's (1994) work is necessary.

\section{Jamaican Informants}

The informants are two speakers of what is called the Broad Jamaican Creole (Baily, 1966) of nearly the same 
age. The first one Mr. Mike (the barber henceforth) is from Hanover in the west of Jamaica. He migrated to Britain when he was 18 years old. Today he is 61 years old. He is a barber in Moss Side, Manchester, England. Most of his customers are West Indies, old and young. He uses the same language (Broad Jamaican Creole) at work, home and everywhere. He is always in touch with the West Indies people. He has little education. He left school before the age of 18 and his reading and writing are not perfect.

The second informant, Mr. Norman (the driver henceforth), is from St. Mary in the north of Jamaica. He migrated to Britain when he was 17. Today he is 59 years old. He worked in two factories in Manchester, as a dry cleaner, and as a carpet fitter before he became a taxi-driver, which is his present job. He also studied for a while in Jamaica and took a course in reading and writing in Manchester. This means that he dealt and is still dealing with different people. Accordingly, his language is expected to be influenced more than that of the first informant.

\section{Data Collection}

Data gathering is based on three factors. Firstly, the author once lived with his informants for one year or so, which enabled him to observe a great deal of the properties of their speech. Secondly, the researchers had already taken permission from the two informants who welcomed the idea of investigating their language by any means. However, to avoid exaggeration and what is called observation paradox, the researcher chose to record their speech when they were unaware that he did so. This-it is hoped-would guarantee spontaneous, i.e. natural speech. Thirdly, in the process, he gave them separately a list of words and sentences to read, some of which are given in Table 1. In addition, examples will be citied in the analysis from the informants' casual speech when appropriate. It is important to mention that the Jamaican Creole transcriptions in this study are based on Cassidy (1961) and Cassidy and Le Page (1967), and the RP counterparts on Gimson (1980) and Roach (2000). The data displayed in Table 1 contains information pertaining to the pronunciation of the interdentals $/ \theta /$ and $/ ð$ / which are taken to be the focus of this investigation.

Transcribing and codifying data were done by the researcher himself, then checked by trained transcribers and a phonologist at the University of Bangor, North Wales. Data was coded manually to categorize the pronunciation of the fricatives in question in the spontaneous speech and list reading of the subjects. For reference regarding Jamaican talk of the subjects, Cassidy (1961), Cassidy and Le Page (1967), Bailey (1966), and Holm (2000) were consulted. As for the Arabic speakers, the author referred to Basalamah (1990) and to his intuition as a native speaker of the dialect spoken by the Arab subjects.

A glance at the data in Table 1 and the informants' (Table 2) makes it clear that there are more differences between the English of our informants and that of RP speakers than their English and the one spoken by other speakers of the Broad Jamaican Creole in general (Cassidy, 1961; Cassidy \& Le page, 1967; Wells, 1973-1982), among others. These differences will be explained in detail in the analysis.

\section{Mousa's (1994) Study}

The subjects of this study were 60 native speakers of Hejazi Urban Dialect (HUD), a variety of Arabic spoken in

Table 1. Words pronounced by the barber and the driver and sentences uttered by them in casual speech.

\begin{tabular}{|c|c|c|c|c|}
\hline Words/phrases/sentences & Driver & Barber & JC & $\mathbf{R P}$ \\
\hline This & /dis/ & /ðIS/ & /dis/ & /ðIS/ \\
\hline Thirty & /te:rti/ & /өe:rti/ & /te:rti/ & $/ \theta_{3}: \mathrm{t} /$ \\
\hline Thing & $/ \operatorname{tin} /$ & $/ \operatorname{tin} /$ & $/ \operatorname{tin} /$ & $/ \theta \mathrm{Iy} /$ \\
\hline Father & /fadə/ & /fadə/ & /fadə/ & /faðə/ \\
\hline Thousand & /taðzən/ & /tauzən/ & /taðzən/ & /சauzənd/ \\
\hline This thing is huge. & /dis tin Iz ju:dz/ & /dis tin Iz ju:dz/ & /dis tin Iz ju:dz/ & /ðIs $\theta$ in Iz hju:dz/ \\
\hline The guys & No Data & /dim gaiz/ & /dım gaiz/ & /ðә gaiz/ \\
\hline Look at them & /lok at dem/ & No Data & /lok at dem/ & /lok ət ðem/ \\
\hline
\end{tabular}


Table 2. The phonemic inventory of the barber and the driver.

\begin{tabular}{|c|c|c|c|c|c|c|c|c|c|}
\hline & Bilabial & Labio-dental & Dental & Alveolar & Post Alveolar & Palato-Alveolar & Palatal & Velar & Glottal \\
\hline Plosive & $\mathrm{p}, \mathrm{b}$ & & & $\mathrm{t}, \mathrm{d}$ & & & & $\mathrm{k}, \mathrm{g}$ & ? \\
\hline Affricate & & & & & $\mathrm{tr}, \mathrm{dr}$ & tf, ds & & & \\
\hline Fricative & B & $f, v$ & $(\theta, \partial) ?^{* 2}$ & s, z & & $\int, 3$ & & & $\mathrm{~h}$ \\
\hline Nasal & M & & & $\mathrm{N}$ & & & & $\mathrm{n}$ & \\
\hline Lateral & & & & 1 & & & & & \\
\hline $\begin{array}{c}\text { Frictionless } \\
\text { continuant or glides }\end{array}$ & $\mathrm{W}$ & & & & $\mathrm{R}$ & & $\mathrm{J}$ & & \\
\hline
\end{tabular}

the urban areas of the Western Province of Saudi Arabia, mainly Makkah, Madinah and Jeddah. They were divided into three groups, 20 in each. None of them had lived in an English-speaking country before the time of study. The first group consisted of pupils at the third year of their intermediate school. Their age ranged from 14 to 16 years. They had been studying English for three years, four hours a week. The second group was pupils of the third year at secondary school. They were between 17 and 18 years of age. They had been exposed to English for six years at a frequency of four hours a week. The third group was university undergraduate students (third year level). They studied different subjects. They had been studying English for nine academic years. In this study, the major aspects of the Saudi learner's interphonology were dealt with. The study drew on the concept of transfer (Broselow, 1983, 1987) and markedness (Eckman, 1977) as two important factors that play major roles in shaping the learners' phonological acquisition. The analysis of the errors made by the learners was eclectic in that it was carried out in such a way that different theories of linear and non-linear phonology as well as theories of language acquisition both first and second, were employed. The study investigated the acquisition of English vowels, both monophthongs and diphthongs, the acquisition of some problematic English consonants for Arabs, such as the voiceless bilabial stop /p/, the voiced labio-dental fricative /v/, the voiceless affricate $/ \mathrm{t} /$, the pronunciation of inter-dentals $/ \theta /$ and $/ ð /$, the pronunciation of consonant clusters and the acquisition of English stress. The analysis shows that the difference in parameter settings (Chomsky, 1981b; Archibald, 1990; Dresher \& Kay, 1990) between Arabic and English could easily explain why certain errors take place. A number of strategies such as sound substitution, consonant reduction, vowel epenthesis, glottal stop insertion, and the misplacement of stress, were employed in accordance with Arabic norms. The analysis also displayed that plenty of the strategies that were resorted to by the learners were similar to those found in child language and other L2 learning studies. The reader is reminded that the current research aims at investigating to what extent the linguistic processes exhibited in creolization and decreolization parallel those manifested by Arab learners of English in the above study in particular, and those of second/foreign language learning in general. But since the data in Mousa (1994) is enormous, care will be taken to cite only relevant information that serves the purpose of our investigation.

\section{Data Elicitation in Mousa (1994)}

Data elicitation involved an experiment with three phases: recognition task, production task and description of pictures. In the production task, a list containing 1012 words in isolation and in carrier sentences was prepared in such a way that vowels, consonants, sequences and word stress were written in separate sections. The learners were given one single section at a time to read. They were instructed to read silently the words and sentences in question twice before actually reading them out. Their utterances were recorded in a sound-treated room in the language laboratory at the English Language Centre, King Abdulaziz University, Jeddah. Recordings of individual subjects were done on separate tapes. Recognition task involved two phases. In the first phase, a list of 172 word pairs containing minimal pairs and pairs of similar words were recorded by a native speaker of English who worked as a professional language instructor. Our learners had to listen to the pairs and judge whether the relevant pairs consisted of similar or different words. In the second phase, a list of 100 word sets each of

${ }^{1}$ The reader will notice that the fricatives in question are cautiously listed in the phonemic inventory of the informants because they managed to produce some instances of them, though one takes it for granted that they are not well-established in their language. Hence, the variable use of these phonemes may be indicative of the fact that they are in the process of acquisition. 
which contained three phonetically similar words was prepared and recorded on a tape by a professional native speaker. The list was handed out to the learners to read silently. They were then instructed to listen to each set and identify the word read out from each group after a short interval between the sets and the word to identify. The third means of data elicitation involved presenting the learners with 104 pictures and instructing them to name objects, describe entities or sequences (events). Their utterances were recorded in a sound-treated room (cf. appendices 1, 2, and 3, in Mousa (1994), for the word lists and pictures). As mentioned earlier, limited data from Mousa (ibid) will be displayed here, due to the fact that only similar behaviours found in the speech of our learners and our Jamaican informants are discussed in the present research. Consider Table 3 for a sample of learners' utterances in Mousa (1994).

\section{Analysis and Discussion}

It is one of the characteristics of West Indian English to realize these sounds as their dental counterparts /t/ and /d/ (Cassidy, 1961; Wells, 1982). According to Holm (2000), many of the linguistic features manifested in Jamaican Creole are also witnessed in other varieties of Atlantic Creole English. Thus, English "th" corresponds to Creole /d/ when voiced ("di”- -the) or /t/, corresponds to unvoiced ("trout"-throat) p. 95. Use of these dental phonemes in the place of their counter inter-dentals is illustrated by rule 1 :

$$
\text { Rule 1: }\left(\begin{array}{l}
+ \text { inter-dental } \\
+/ \text {-voice }
\end{array}\right) \rightarrow(\text { dental })
$$

This reads: an inter-dental, voiced or voiceless becomes dental.

The above two fricatives are lacking in many languages of the world. This suggests that the speakers of these languages will experience some difficulty when learning languages in which $/ \theta /$ and /ð/ are part of the phonemic inventories. Indeed, speakers from different linguistic backgrounds have been reported to struggle when learning these two fricatives in English (cf.5). Although $/ \theta /$ and $/ \delta /$ are legitimate phonemes in classical Arabic, standard Arabic and some dialects of Arabic, speakers of many Arabic dialects are known for substituting /t/ and /d/ respectively for the above fricatives. Speakers of these dialects, including speakers of Hejazi Urban Dialect (spoken in the Western Province of Saudi Arabia), have the tendency of producing these stops instead of the fricatives in question when learning English as a foreign language.

Both Arabic L1 learners of English and speakers of Jamaican Creole seem to have substituted these two stops which are part of their phonemic inventories for the fricatives which are not (c.f. Tables 1-3). But these substitutions are not random. In other words, "sounds which share some feature, say, in point or manner of articulation

\begin{tabular}{|c|c|}
\hline Gloss & Pronunciation \\
\hline Both & /bo:t/ \\
\hline Thin & $/ \mathrm{tm} /$ \\
\hline This & /dis/ \\
\hline Three & /trr:/ \\
\hline Arthur & /artar/ \\
\hline phantham & /fantam/ \\
\hline Those & /do:s/ \\
\hline Thatcher & /tatfar/ \\
\hline Think & $/ \mathrm{tmgk} /$ \\
\hline Thin & $/ \mathrm{tm} /$ \\
\hline Thus & /das/ \\
\hline Athens & /atmz/ \\
\hline
\end{tabular}


will very often change in the same direction” (Arlotto, 1972: p. 71). This is clearly seen in that the voiceless alveolar stop is used for the voiceless inter-dental fricative and the voiced alveolar stop for the voiced inter-dental fricative. The behaviour of Arab learners of English and the speakers of Jamaican Creole with respect to the above phonemes can be explained in terms of linguistic universals (cf. Holm, 2000). According to this, sounds that are found throughout most of the world's languages, e.g., $/ \mathrm{m} / \mathrm{or} / \mathrm{d} /$, are more likely to survive in Pidgins and Creoles than sounds that are relatively rare, e.g. $/ \theta /$ and $/ \delta /$. Indeed, these two sounds are exceedingly rare in the world's languages and are usually replaced by /t/ and /d/, respectively. Absence of these two fricatives in the phonemic charts of many languages indicates that they are marked (Jakobson, 1968). Their acquisition comes with more exposure to English. Furthermore, the history of these two fricatives reveals that they are originally /t/ and /d/ respectively. For instance, in 1382 the word "autentick", for instance, was attested in English as a loan word from old French "autentique". Later on, it was discovered that it came originally from the ancient Greek "authentikos". Later on, in 1630, the spelling "authentique" emerged, and in 1682 it changed into "authentick". Likewise, until the middle of the $14^{\text {th }}$ century, the word "throne" was spelled "trone", from old French "trone" which in turn was discovered to have originated from the Greek "thronos". As a result, a new spelling with the fricative $/ \theta /$ spread and became accepted; /t/ was replaced eventually by $[\theta]$ in spoken English, (c.f. Arlotto 1972).

As for the voiced fricative /ð/, in old English father and mother used to be pronounced as mōdor and foeder respectively, hence reporting a sound change which involved a shift of the stop /d/ to the fricative / $/$ / in between vowels (Arlotto, ibid: 71). Today, this is well attested in Spanish in what is known as "spirantization". In this language voiced stops change into voiced spirants (fricatives) intervocalically. Thus, banca-"bench", de-

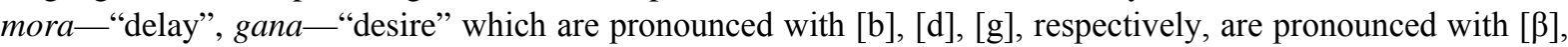

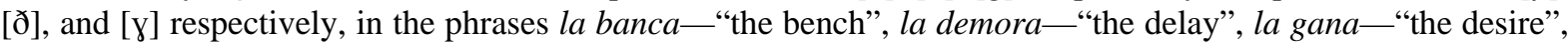
respectively. Rule 2 is postulated to account for the above Spanish phenomenon.

Rule 2: [b, d, g] $\rightarrow[\beta, \partial, \mathrm{y}] / \mathrm{v} \_$_. (Hyman, 1975)

Rule 2 above reads: underlying ( $b, d, g)$ are converted to $[\beta, \gamma, \gamma]$ between vowels. In terms of distinctive features, this rule appears as follows:

$$
\begin{aligned}
& \begin{array}{lll}
\text { C } & \text { V }
\end{array} \\
& \text { Rule 3: }\left[\begin{array}{l}
\text { +voice } \\
\text {-nasal }
\end{array}\right] \rightarrow[+ \text { cont }] /[+ \text { syll }] \_[\text {_ }
\end{aligned}
$$

According to this rule (rule 3), an oral voiced consonant becomes a continuant (i.e. a fricative) between vowels. One can see that the above change is context-sensitive, which tends to produce more complex segments (Hyman, 1975). It follows from this that in both creoles and inter-languages speakers opt for less complex gymnastics to get their messages across. Perhaps this explains the absence of voiced fricative allophones for [b, d, g] in Papiamentu, although it is a Spanish-based creole (Holm, 2000). Provided that the fricatives $/ \theta /$ and $/ \delta /$ are lacking in the substrate languages of Jamaican Creole, then one can safely argue that our informants are preserving Old English pronunciations as suggested by Holm (2000). Creoles based on different superstrate languages have been reported to preserve archaic usages of different aspects of language (cf. Holm, 2000). For instance, initial /f/ in Latin (e.g. "facere”- “do, make”) becomes /h/ in earlier Spanish "hacer" and then /8/ in the modern standard. Yet, the /h/ pronunciation survives in Papiamentu "hasi"- “do, make" (Holm, 2000). Moreover, in grammar, speakers of a number of English-based creoles use "from" as a conjunction with the temporal meaning of "since", e.g. "From I was a child I do that". According to Holm, the last recorded use of 'from' with this meaning in The Oxford English Dictionary was in 1602, indicating that it was still current in standard speech when English invaded the Caribbean in the $17^{\text {th }}$ century. One important fact concerning the fricatives in question is pointed to by Gimson (1980). He mentions that "in popular London speech, the difficulties of the dental articulation may lead to their replacement by labio-dental fricatives, e.g. throw it, Smith (/frov It, smif/), mother, breath in (/m^və, bri:v $\mathrm{In} /)$. In this kind of speech, too, other alveolar articulations may be heard for the weak /ð/, e.g. all the way /っ:l də weI/, in the morning /m də mə:nın/.” (pp. 184-185). Although the /ð v/ alternation does not figure in the speech of the cab driver, the $/ \delta \sim d /$ alternation does. Thus, it is not unwarranted that he is not decisive whether it is more correct to use /ð/ or /d/, as he is exposed to both. Indeed, he once mentioned that he had many relatives and friends in London with whom he socialized. This might explain the variation in the use of this fricative sound in his speech.

In child language, these two sounds are among those acquired late by the child, and in most cases they are 
substituted by the stops /t/ and /d/, respectively (Cruttenden, 1979). The sound / $\theta /$, however, is also replaced by an acoustically similar fricative, i.e. /f/ (Ferguson, 1973). Winitz (1969) reports [ $\phi]$, as a substitute for / $/$ / and [d] or [t] for / $/$. The sound substitutions in (5) below display the different renditions for the fricatives in question in the interphonologies of speakers from different linguistic backgrounds.

(5) Renditions of English fricatives by different L2 speakers:

English /ð/ to [z] by French speakers (Weinreich, 1966).

English / / / to [t] by Punjabi/Urdu speakers (Verma et al., 1992; Denison, 1966).

English /ð/ to [v] by Hungarian speakers (Nemser, 1971).

English / $\theta /$ to [f] by Japanese speakers (Sheldon \& Strange, 1982).

English / $/$ / to [s] by Dutch speakers (James, 1989).

English $/ \theta$, ठ/ to [t, d] by Russian speakers (Weinreich, 1953).

English $/ \theta, \partial /$ to $[\mathrm{s}, \mathrm{z}]$ by Japanese speakers (Weinreich, 1953).

English $/ \theta, \partial /$ to $[\mathrm{f}, \mathrm{d}]$ by Chinese speakers (Hung, 2004).

English $/ \theta$, ð/ to [t] by Finglish ${ }^{2}$ speakers (Randell, 2004).

One can notice that all the above sound substitutions made by the child are also attested in adult L2 learner's speech. Regarding our learners, the speakers of Hejazi Arabic, although the two sounds are authentic Arabic phonemes, they are not part of their phonemic inventory (Basalamah, 1990; Ingham, 1971; Omar, 1975). Nevertheless, speakers of this dialect are fully aware of the fact that these are genuine Arabic sounds and do really pronounce them authentically should they need to. That is, our learners do pronounce $/ \theta /$ and $/ \delta /$ when speaking formally. Yet, it is quite interesting that these speakers opt for $/ \mathrm{t}, \mathrm{d} /$ instead, perhaps being less marked than the fricatives concerned. Another possible explanation for this tendency is to assume the strong effect of L1 (i.e. Hejazi Urban dialect). However, the renditions displayed in (5) should not downplay the fact that /t/ and /d/ are the most favourite substitutes for the fricatives in question (Gilbers et al., 2007; Peust, 1996; Hattem, 2009). We may draw on Jackobson's (1968) markedness theory to explain this. Jackobson claims that stops are acquired before fricatives and serve as substitutes for fricatives. This claim, according to Atkinson (1982: p. 33), "is related to the claim that, in the languages of the world, we can find instances which lack fricatives while containing stops but no instances for which the opposite is true. Thus, if a language has fricatives then it has stops”.

In the situations where the speakers of creole come in contact with the speakers of the superstrate language, i.e. the lexical donor language, there has been a historical tendency for the Creole to shed its most salient features which set it apart from the donor language which is usually European. This process is known as "decreolization". It results in "a continuum of varieties from those farthest from the superstrate (the basilect) to those closest (the acrolect), with mesolectal or intermediate varieties between them (Holm, 2000: p. 10). The extent to which an individual speaker is decreolized will, of course, be determined by the amount of the encounter he/she has with acrolectal speakers. That is, an individual's linguistic development is socially determined (Schumann \& Stauble, 1983). For instance, Rickford (1999) reports that Mr. Seymour, a cane-cutter who can speak a basilectal/lower mesolectal variety of creole, rarely uses this in the interview situations. As a "big-time" contractor, with plenty of occupational and other contacts outside the village where he lives, he generally uses an upper mesolectal/acrolectal variety with his interviewees. Mr. Seymour's younger daughter Katherine, who goes to school, however, speaks what Rickford (ibid) calls an almost flawless acrolet, and amazingly enough, seems incapable of speaking the basilectal and lower mesolectal realizations of creole.

According to Le Page and Tabouret-Keller (1985), commenting on a speaker of Belizean English-based creole who left the creole environment, she was much on her guard linguistically than she had been earlier when she had been one of the "broader creole speakers". They add, however, that other Belizeans who did not have the same chance and therefore had to remain as agricultural labourers or as factory workers exhibited less linguistic change. From the above situation Rickford (ibid) concludes that, urged by the awareness of the so called social prestige and stigma associated with the varieties of Belizean speech (hence a sociopsychological motive), those speakers did their utmost to increase their capability in using lects closer to the standard English end of the continuum.

Despite the fact that it is one of the characteristics of West Indian English to realize these two sounds as their dental counterparts /t/ and /d/ (Cassidy, 1961; Wells, 1982; Holm, 2000), one of the informants (the cab driver) produces RP inter-dentals. This happens when he emphasizes something. For instance, in casual speech he says /sivin $\theta 3$ :rtr/ "seven thirty" and /ðıs do:r/ "this door", pointing to the door. It is quite surprising that the other in-

${ }^{2}$ Finglish is a variety of English spoken by Finnish immigrants in the United States and Canada. 
formant does not report a single instance of a successful utterance of either of the fricatives in question. The point here is self-explained. That is, the driver's encounters with speakers of standard English must have lead to the enhancement of his pronunciation. On the other hand, the good performance of our English L2 learners pertaining to these two fricatives may be explained as follows. We assume that our Arab learners' phonological level which reflects their mental representation of these two fricatives has $/ \theta, \mathrm{\partial} /$ and $/ \mathrm{t}, \mathrm{d} /$. The phonetic level has them as $/ t, d /$ only. At an early stage of their L2 linguistic development, there is a phonological rule merging $/ \theta$, ð/with /t, $d /$, and because the learners lack experience as to which of the pairs is used in RP, they transfer the sounds they normally use in Hejazi Arabic into English. But more exposure to RP through formal instructions and/or encounters with RP speakers is expected to awaken them to use more accurate pronunciation of these fricatives. Our cab driver and advanced learners' use of these fricatives lends support to this point. However, one limitation of this study is the number of informants. As we have seen in the analysis, a great deal of their behaviour resembles that of other Jamaican and Caribbean speakers, as indicated by Cassidy (1961), Bailey (1966), Cassidy and Le Page (1967), Bickerton (1995), and Holm (2000), among others. In addition, findings of case-studies, with limited numbers of informants, have enormously enriched the area of applied linguistics (cf, Burling, 1978; Smith, 1973).

\section{Conclusion}

This paper is an investigation of the extent to which linguistic processes found in creolization are similar to those manifested by Arab learners of English, and also those found in child language and second/foreign language in general. The link between second/foreign language and historical change is highlighted. The performance of Saudi university students was compared to the speech of two speakers of Broad Jamaican Creole and to data from child language, with a particular focus on the pronunciation of English inter-dental fricatives $/ \theta /$ and $/ ð /$. It was found that learning in the above three situations took place according to the same principles. Furthermore, the sound substitutions made in the three situations (i.e. [t], [d] respectively) were the same as those witnessed in historical sound change. These findings can have effects on teaching and learning approaches and also on curriculum design.

\section{Acknowledgements}

This research was made possible through a grant from the Deanship of Scientific Research, King Abdulaziz University, Jeddah, Saudi Arabia (Project No 427/452). The author wishes to acknowledge that.

\section{References}

Archibald, J. (1990). The Acquisition of English Metrical Parameters by Polish Speakers: Quantity-Sensitivity and Adult Access to OG. Paper Presented at the Boston University Conference on Language Development.

Arlotto, A. (1972). Introduction to Historical Linguistics. Boston: Houghton.

Atkinson, M. (1982). Explanations in the Study of Child Language Acquisition. Cambrige: CUP.

Bailey, B. (1966). Jamaican Creole Syntax. Cambridge: CUP.

Baxter, A., Lacchesi, D., \& Guimaraes, M. (1997). Gender Agreement as a Decreolizing Feature of an Afro-Brazilian Dialect. Journal of Pidgin and Creole Languages, 12, 1-57. http://dx.doi.org/10.1075/jpcl.12.1.02bax

Bickerton, D. (1995). Creoles and the Bankruptcy of Current Acquisition Theory. In W. Herman (Ed.), Creole Languages and Language Acquisition. Berlin: Mouton de Grunter.

Bickerton, D., \& Odo, C. (1976). General Phonology and Pidgin Syntax. Vol. 1 of Final Report on National Science Foundation Grant No. Gs-39748.

Broselow, E. (1983 \& 1987). Non-Obvious Transfer: On Predicting Epenthesis Errors. In S. Gass and G. Selinker (Eds.), Language Transfer in Language Learning (pp. 269-280). Rowley: Newbury House.

Brown, R. (1973). A First Language: The Early Stages. Cambridge, MA: Harvard University Press. http://dx.doi.org/10.4159/harvard.9780674732469

Burling, R. (1959). Language Development of a Garo- and English-Speaking Child. Word, 15, 45-68.

Cassidy, F. G. (1961). Jamaican Talk. London: Macmillan.

Cassidy, F. G., \& Le Page, R. B. (1967). Dictionary of Jamaican English. London and New York: CUP. 
Chomsky, N. (1981b). Principles and Parameters in Syntactic Theory. In N. Hornstein, \& D. Lightfoot (Eds.), Explanation in Linguistics (pp. 32-75). London: Longman.

Cook, V. (1993). Linguistics and Second Language Acquisition. Basingstoke: Macmillan.

Cruttenden, A. (1979). Language in Infancy and Childhood. Manchester University Press.

Denison, N. (1966). The Nature and Diagnosis of Interference Phenomena. Philippine Journal for Langauge Teaching, 4.

Dresher, B., \& Kaye, J. (1990). A Computational Learning Model for Metrical Phonology. Cognition, 34, 137-195. http://dx.doi.org/10.1016/0010-0277(90)90042-I

Eckman, F. (1977). Markedness and the Contrastive Analysis Hypothesis. Language Learning, 27, 315-330. http://dx.doi.org/10.1111/j.1467-1770.1977.tb00124.x

Ferguson, C. (1973). Fricatives in Child Language Acquisition. Papers and Reports on Child Language Development (Linguistics, Stanford University), 6, 61-85.

Gilbers, D., Lowie, W., \& Wester, F. (2007). Substitution of Dental Fricatives in English by Dutch L2 Speakers. Language Sciences, 29, 477-491. http://dx.doi.org/10.1016/j.langsci.2006.12.029

Gimson, A. C. (1980). An Introduction to the Pronunciation of English. London: Edward Arnold.

Greenberg, J. (1966). Universals of Language. Cambridge, MA: MIT Press.

Hattem, J. (2009). Substitution Patterns for English Interdental Fricatives by L1 Latin American Spanish Speakers. http://andromeda.rutgers.edu/ hattem/Academic\%20Research/Sample\%20Research\%20Paper\%20Substitution_Patterns_f or_EnglishInter-Dental_Fricatives_(David_J_Hattem)_FINAL_PAPER.pdf

Holm, J. (2000). An Introduction to Pidgins and Creoles. Cambridge: CUP. http://dx.doi.org/10.1017/CBO9781139164153

Hung, T. (2004). Innovation in Inter Language Phonology: Evidence from Hong Kong English. http://www.waseda.jp/ocw/AsianStudies/9A-77WorldEnglishSpring2005/LectureNotes/03_HKE_TonyH/HKE_unit5.pdf

Hyman, L. (1975). Phonology: Theory and Analysis. Winston, New York: Holt Rinehart.

Ingham, B. (1971). Some Characteristics of Meccan Speech. Bulletin of the School of Oriental and African Studies, 34, 273279. http://dx.doi.org/10.1017/S0041977X00129544

Jakobson, R. (1968). Child Language, Aphasia and Phonological Universals. The Hague: Mouton.

James, A. (1989). Linguistic Theory and Second Language Phonological Learning: A Perspective and Some Proposals. Applied Linguistics, 10, 367-381. http://dx.doi.org/10.1093/applin/10.4.367

Le Page, R. B., \& Tabouret-Keller, A. (1985). Acts of Identity: Creole-Based Approaches to Language and Ethnicity. Cambridge: CUP.

Lefebvre, C., White, L., \& Jourdan, C. (2003). L2 Acquisition and Creole Genesis. Amesterdam: Benjamins.

Moscowitz, A. (1975). The Two-Year-Old Stage in the Acquisition of English Phonology. In C. Ferguson, \& D. Slobin (Eds.), Studies of Child Language Development. Holt Rinehart.

Mousa, A. (1994). The Interphonology of Saudi Learners of English. Unpublished PhD Dissertation: University of Essex.

Nemser, W. (1971). Approximative Systems of Foreign Language Learners. IRAL, 9, 115-123. http://dx.doi.org/10.1515/iral.1971.9.2.115

Omar, M. (1975). Saudi Arabic Urban Hijazi Dialect. Foreign Service Institute: Washington.

Patrick-Andre, M. (2006). Second Language Acquisition and Creolization: Same (i-) Processes, Different (e-) Results. Journal of Pidgin and Creole Languages, 21, 231-274. http://dx.doi.org/10.1075/jpcl.21.2.01mat

Peust, C. (1996). Sum: Th-Substitution. The Linguist List 7.1108. http://linguistlist.org/issues/7/7-1108.html

Randell, K. (2004). Finglish. http://works.bepress.com/cgi/viewcontent.cgi?article=1013\&context=kent randell

Rickford, J. (1999). Phonological and Grammatical Features of African American Vernacular (AAVE). Malden, MA: Blackwell Publishers.

Roach, P. (2000). English Phonetics and Phonology. Cambridge: CUP.

Schumann, J. (1978b). The Pidginization Process: A Model for Second Language Acquisition. Rowley, MA: Newbury House.

Sheldon, A., \& Strange, W. (1982). The Acquisition of /r/ and /l/ by Japanese Learners of English: Evidence that Speech Production Can Precede Speech Perception. Applied Psycholinguistics, 3, 243-261.

http://dx.doi.org/10.1017/S0142716400001417

Smith, N. V. (1973). The Acquisition of Phonology. Cambridge: CUP.

Verma, M., Firth, S., \& Corrigan, K. (1992). The Developing Phonological System of Panjabi/Urdu Speaking Children Learning English as a Second Language in Britain. In A. James, \& J. Leather (Eds.), New Sounds, 92, 174-199. 
Washabaugh, W. (1977). Constraining Variation in Decreolization. Language, 53, 329-352.

Weinreich, U. (1953, 1966). Languages in Contact. The Hague: Mouton.

Wells, J. C. (1973). Jamaican Pronunciation in London. Oxford: Basil Blackwell.

Wells, J. C. (1982). Accents of English beyond the British Isles. Cambridge: CUP.

Winitz, H. (1969). Artilculatory Acquisition and Behaviour. New York: Appleton-Century-Crofts. 